\title{
NORMATYWNOŚĆ I DESKRYPTYWNOŚĆ WNIOSKOWANIA DIAGNOSTYCZNEGO W NURCIE EVIDENCE-BASED MEDICINE
}

\begin{abstract}
NORMATIVE AND DESCRIPTIVE ASPECTS OF CLINICAL REASONING WITHIN EVIDENCE-BASED MEDICINE Evidence-based medicine (EBM) provides basic rules for diagnostic procedures. A physician is required critically to appraise clinical evidence and to internalize the quantitative approach to data processing in her practice. There is a common agreement that knowledge of statistical methods is among the core skills of a competent physician. This includes Bayes Theorem. The key role of statistics in medicine gives rise to a normative way of clinical reasoning. However, many researches point out that medicine practitioners do not follow this normative way. Instead, they use common decision strategies mostly based on heuristics. This situation opens a gap between normative and descriptive aspects of clinical reasoning. Consequently, many experts are prone to draw unfavorable conclusions about rationality of clinical decisions. This paper characterizes normative and descriptive aspects of clinical reasoning regarding the concepts of Bayes Theorem and heuristics. It differentiates between two interpretations of heuristics: one presented by Amos Tversky and Daniel Kahneman and another by Gerd Gigerenzer. It is argued that clinical decisions based on heuristics are not necessarily flawed and irrational.
\end{abstract}

Keywords: dual-track theory, heuristics, clinical decision making, theory of decision, Bayes Theorem

Studia lekarskie służą temu, by nabyć umiejętność wyciągania wniosków z uzyskiwanych danych. Przynajmniej tak twierdzą autorzy podręcznika dla studentów medycyny - Jan Tatoń i Anna Czech (2002: 17)ํ․ Stwierdzenie to jest dla mnie atrakcyjne $\mathrm{z}$ dwóch powodów. Po pierwsze, przypomina o znaczącym związku między medycyną a logiką. Warto pamiętać, że w polskiej lite-

\footnotetext{
* Instytut Filozofii, Uniwersytet Warszawski, ul. Krakowskie Przedmieście 3, oo-927 Warszawa, rutkiewicz.w@gmail.com.

${ }^{1}$ „Tak więc lekarz i zespół leczący zbierają jednostkowe dane, aby stosując naukową analizę, wyciągnąc z nich ogólniejsze wnioski. Całe studia lekarskie służą temu właśnie celowi”.
} 
raturze z zakresu filozofii medycyny istnieje bogata tradycja badań logicznych (Szumowski 2005). Po drugie, daje pewną wskazówkę co do ogólnego charakteru myślenia lekarskiego - jest on mianowicie naukowy. Postulat ten jest zgodny z założeniami nurtu evidence-based medicine (nazwa ta będzie pojawiać się tu wielokrotnie bądź w formie skróconej - EBM, bądź też spolszczonej medycyna wiarygodna - zgodnie z propozycją Zbigniewa Szawarskiego). Zgodnie z postulatem EBM myślenie lekarza powinno być naukowe: powinno opierać się na wiarygodnych informacjach i prowadzić do wiarygodnych wniosków. Kryterium naukowości odwołuje się więc bezpośrednio do pojęcia wiarygodności. Jej gwarantem ma być poprawnie przeprowadzony wywiad, badania przedmiotowe i testy laboratoryjne. Czy jednak obecność tych trzech elementów w postępowaniu klinicznym od razu oznacza, że wnioski wyprowadzane przez lekarza są wiarygodne?

Podręcznik medyczny to korpus wiedzy niezbędnej lekarzowi do prowadzenia praktyki. Znajomość symptomów chorobowych, ich przyczyn fizjologicznych, patofizjologii chorób czy metod ich wykrywania wyposaża lekarza w teoretyczne podstawy. Te zapoczątkowują proces diagnozy, prowadząc przez terapię do wyleczenia. Po drodze lekarz musi zmierzyć się z koniecznością podjęcia wielu decyzji. Atul Gawande (2012), światowej sławy amerykański chirurg, przekonuje, że decyzje te podejmowane są w skrajnie złożonych warunkach. Lekarz mierzy się bowiem nie tylko $\mathrm{z}$ chorobą in abstracto, lecz także $\mathrm{z}$ trudnościami komunikacyjnymi, z systemem finansowania służby zdrowia, z czasem, z liczbą pacjentów, z systemem prawnym, z zatroskanymi rodzinami, a także z samym sobą (Reszka 2017). Istnieje bogata literatura opisująca, jak faktycznie działają lekarze. Nurt EBM określa zasady tego, w jaki sposób powinni to robić. Swoje początki zawdzięcza on bowiem odwróceniu się od tradycyjnych metod podejmowania decyzji lekarskich i zwrotowi ku metodom ufundowanym na standardach naukowych. Metody tradycyjne opierają się w głównej mierze na wiedzy i profesjonalnej intuicji eksperta, co będę nazywał „starą szkołą”. Metody EBM charakteryzuje z kolei metodologiczny rygor, klarowność i obiektywizm reguł przebiegu procesu decyzyjnego, w którym lekarz staje się poniekąd naukowcem. Nurt ten będę określał mianem „nowej szkoły”.

Na decyzje, które podejmuje lekarz, można patrzeć z punktu widzenia deskryptywnego (analizując, co faktycznie lekarze robią) i z punktu widzenia normatywnego (analizując, co zgodnie z pewną teorią powinni robić). W artykule dążę do rozdzielenia tych dwóch aspektów w kontekście decyzji lekarskich i do scharakteryzowania ich w kategoriach nurtu EBM oraz heurystyk. W przypadku heurystyk konieczne będzie odróżnienie sposobu, w jaki rozumie je Daniel Kahneman, od interpretacji Gerda Gigerenzera. Uściślenia wymaga również pojęcie „decyzji”. Zgadzam się z Tatoniem i Czech, że podsta- 
wową umiejętnością lekarza jest prawidłowe wyciąganie wniosków. Decyzję będę rozumiał jako wniosek, a proces decyzyjny jako wnioskowanie. Biorąc zaś pod uwagę złożoność warunków pracy lekarza, skupię się wyłącznie na etapie diagnozowania choroby i wnioskowaniach prowadzonych tylko w celu ustalenia rozpoznania.

\section{KRÓTKA HISTORIA EVIDENCE-BASED MEDICINE}

Terminem evidence-based medicine pierwszy raz posłużono się $\mathrm{w}$ roku 1990 (por. Gajewski, Jaeschke, Brożek 2008: 19). Dwa lata później na łamach „Journal of American Medical Association” tzw. Grupa Robocza EBM pod przewodnictwem Gordona H. Guyatta przedstawiła podstawowe zasady EBM, wskazując jednocześnie, że jest to zmiana paradygmatu medycznego (EBM Working Group 1992: 2421). Odwołanie do nomenklatury Kuhna (2009) nie jest przypadkowe. Nurt EBM miał bowiem stanowić naukową rewolucję: medycyna retroaktywna, polegająca na przeciwdziałaniu chorobie, przestała być wystarczająca. Zwiększyło się zapotrzebowanie na działania prewencyjne, na medycynę prospektywną. Dolegliwości pacjentów zaczęto postrzegać nie tylko jako „przypadki”, lecz także (a może bardziej) jako „problemy do rozwiązania”. Problemy o dużym stopniu złożoności.

Guyatt (1991) opisał przypadek siedemdziesięcioletniego pacjenta cierpiącego według podejrzeń internisty na niedobór żelaza. Jakie są kolejne działania lekarza w tego typu sytuacji? W podejściu zgodnym ze starą szkołą internista konsultuje się z bardziej doświadczonym lekarzem, który proponuje przeprowadzenie testów na stężenie żelaza we krwi. Jeśli wynik testu potwierdza podejrzenie niedoboru, tj. stężenie żelaza okaże się poniżej normy, to lekarz powinien rozpocząć leczenie anemii. Jeśli nie, powinien zdać się na intuicję, przeprowadzić konsultacje z innymi lekarzami, powrócić do podręczników i badać kolejne hipotezy. W podejściu propagowanym przez nową szkołę lekarz najpierw przeszukuje literaturę medyczną pod kątem skuteczności testu sprawdzającego stężenie żelaza we krwi. Następnie przed wykonaniem badania sprawdza, jak wysokie jest prawdopodobieństwo (pre-test likelihood), że u pacjenta wystąpi anemia ${ }^{2}$. Po przeprowadzeniu badania oblicza prawdopodobieństwo wystąpienia anemii z uwzględnieniem wyniku testu oraz uzyska-

${ }^{2} \mathrm{~W}$ dalszej części tekstu pojawi się również pojęcie prawdopodobieństwa wystąpienia choroby przed badaniem, pochodzące od angielskiego „pre-test probability”. Warto zaznaczyć, że „pre-test likelihood” i „pre-test probability” nie są analitycznie równoważne. Nie można ich zatem stosować wymiennie. 
nych z literatury danych co do jego skuteczności. Dopiero na tej podstawie podejmuje kolejne działania. Odróżnienie podejść, które Guyatt odpowiednio określił jako „metodę przeszłości” (the way of the past) i „metodę przyszłości” (the way of the future) (Guyatt 1991), na dobre zagościlo w pracach zwolenników EBM (Davidoff i in. 1995). Podejście lekarza nowej szkoły streszcza się w czterech krokach: sformułowanie problemu klinicznego („czy pacjent ma anemię?”), przeszukanie najnowszej literatury medycznej w poszukiwaniu odpowiednich danych, ocena uzyskanych z literatury dowodów pod kątem ich wiarygodności i użyteczności („z jaką precyzją test wykrywa anemię?”, „jak często anemia występuje u pacjentów podobnych do mojego?”), w końcu zastosowanie uzyskanych danych $\mathrm{w}$ postępowaniu klinicznym (obliczenie prawdopodobieństwa przed i po wykonaniu testu z uwzględnieniem uzyskanych danych, decyzje terapeutyczne) (Rosenberg, Donald 1995: 1122).

Członkowie Grupy EBM wprost twierdzą, że dobry lekarz wykorzystuje zarówno najlepszej jakości dowody, jak i dokonuje rzetelnej ekspertyzy klinicznej (Sackett i in. 1996: 71-72). Podkreślają przy tym również, że decyzje lekarskie powinny opierać się na bardzo konkretnych przesłankach, w szczególności na danych dotyczących zarówno konkretnych pacjentów, jak i całej populacji. Nazwali je pięcioma powiązanymi ideami (five linked ideas). To realny problem kliniczny wyznacza właściwy rodzaj dowodów, a nie nawyki lekarzy czy tradycja. Szukając najlepszej jakości przesłanek, należy integrować indywidualne doświadczenie lekarskie $\mathrm{z}$ wiedzą epidemiologiczną, biostatystyczną oraz $\mathrm{z}$ wiedzą o patofizjologii chorób. Wyniki tych poszukiwań mają sens tylko o tyle, o ile są wykorzystywane w działaniach na rzecz dobra pacjentów i są poddawane ocenie (Sackett, Rosenberg 1995: 621). Wypracowując zasady działań lekarzy, członkowie Grupy Roboczej EBM stawiają przed nimi dwa zasadnicze wymogi: umiejętność krytycznej oceny dowodów (critical appraisal) oraz zrozumienie roli metod ilościowych $\mathrm{w}$ medycynie (quantitative approach) (EBM Working Group 1992: 2424). Są one związane bezpośrednio z dwoma ważnymi zagadnieniami poruszanymi niżej: przyjmowanymi przesłankami i opartym na nim wnioskowaniu lekarza. W perspektywie rozważań o racjonalności decyzji klinicznych większy nacisk kładę na zrozumienie metod ilościowych przy wyprowadzaniu wniosków z przesłanek, stąd tylko pokrótce, w charakterze wprowadzenia do tematu, omówię zagadnienie roli dowodów w praktyce EBM. 


\section{COCHRANE COLLABORATION, HIERARCHIA DOWODÓW I RCT}

Krytyczna analiza dowodów jest sensowna o tyle, o ile nie podporządkowuje sobie całego procesu terapeutycznego. Już w 1995 roku, aby być na bieżąco, lekarz musiałby czytać 17 artykułów dziennie (Davidoff i in. 1995: 1085). Dziś ta liczba jest z pewnością znacznie większa. W celu ułatwienia lekarzom dostępu do najnowszej, rzetelnej wiedzy medycznej i uniknięcia sytuacji, w której lekarz spędzałby czas w czytelniach zamiast z pacjentami, w 1992 r. z inicjatywy Iana Chalmersa w ramach projektu Cochrane Collaboration powstało pierwsze Cochrane Center (Gajewski, Jaeschke, Brożek 2008: 20). Zajmuje się ono analizą aktualnych danych klinicznych oraz tworzeniem ich systematycznych przeglądów. Chalmers podkreśla, że pomysł nawiązuje do pracy lekarza Archiego Cochrane'a nawołującego już od lat siedemdziesiątych ubiegłego wieku do oparcia praktyki klinicznej na wiarygodnych informacjach uzyskiwanych z randomizowanych badań klinicznych (randomized conrolled trials - RCT) (Chalmers 1993: 157-158). Grupa recenzentów ma za zadanie opracować zestaw artykułów dotyczących danej dziedziny (np. ciąży i narodzin), a następnie powstały pod okiem grupy redaktorów przegląd umieścić w Bibliotece Cochrane'a. Za jej pośrednictwem lekarz może otrzymać kompleksowy zestaw najnowszych danych potrzebnych mu do podjęcia „lepszych decyzji”.

Pogląd Cochrane'a, że wiarygodne informacje medyczne pochodzą z RCT, stanowi tylko fragment szerszego trendu, który w najbardziej skrajnej postaci z góry dyskredytuje wszystkie nierandomizowane badania (Abel, Koch 1999: 487). RCT niewątpliwie stały się standardem w medycynie, narosło jednak wokół nich wiele kontrowersji (Grossman, Mackenzie 2005). Przyjmuje się, że istnieją dwa główne rodzaje badań: eksperymentalne (przeprowadzane w warunkach kontrolowanych) i obserwacyjne, wolne od interwencji badaczy. W zależności od przyjętego kryterium klasyfikacja ta ulega dalszemu uszczegółowieniu (Gajewski, Jaeschke, Brożek 2008: 54). Ważne z punktu widzenia tego artykułu jest jednak to, że badania eksperymentalne, a w szczególności RCT, uznawane są za wiarygodniejsze niż badania obserwacyjne. Stosowana $\mathrm{w}$ nich metodologia ma zapewniać najbardziej precyzyjne odpowiedzi na pytania stawiane przez badaczy. W warunkach kontrolowanych ryzyko przecenienia wartości uzyskanego efektu ma nie występować i dlatego randomizowane badania kliniczne stoją na szczycie hierarchii dowodów EBM.

Randomizowane próby kliniczne stanowią odmianę prospektywnych badań kohortowych, w których dokonuje się podziału na grupy: badawczą (eksponowaną na działanie badanego czynnika) i kontrolną (nieeksponowaną na badany czynnik). Odpowiednio zaprojektowane randomizowane badanie 
kliniczne powinno zapewnić wystarczające świadectwa, by stwierdzić, czy badany czynnik (np. lek) prowadzi w grupie podmiotów poddanych temu czynnikowi do zmian (np. wyzdrowienia). Prospektywność RCT odnosi się do kierunku przeprowadzanego w nim wnioskowania: od przyczyny, którą jest badany czynnik, do skutku, czyli wywołanych zmian. Wyróżnikiem tego rodzaju badań jest metoda przydziału do poszczególnych grup, który dokonywany jest w sposób losowy (randomizowany). Gdy to możliwe, stosowane jest w nich również zaślepienie prób, polegające na ograniczeniu zarówno badanym, jak i badającym dostępu do wiedzy o przydziale poszczególnych uczestników do grupy badawczej lub kontrolnej. Dzięki randomizacji ograniczany jest wpływ zmiennych zakłócających. W nurcie EBM jest to gwarant wiarygodności uzyskiwanych wyników (Rzepiński 2012: 14-16).

Wraz z powstaniem takiego przekonania pojawiły się jednak głosy krytyczne. John Worrall (2010: 360) pytał prowokacyjnie, czego właściwie dowodzą świadectwa uzyskiwane w badaniach randomizowanych. Odwoływał się przy tym do istotnego dla metodologii badań podziału na trafność wewnętrzną i zewnętrzną (internal and external validity). Pierwszy rodzaj trafności polega na takim wyznaczeniu warunków eksperymentu, by uzyskać jak najwyraźniejszą różnicę między grupami badawczymi. Drugi rodzaj określa stopień, w jakim wyniki eksperymentu można odnieść do docelowej populacji. Rezultaty badań randomizowanych, jak zauważa Worrall, dotyczą tylko warunków eksperymentalnych, a więc są trafne wewnętrznie. Lekarz natomiast w swojej praktyce potrzebuje dowodów, które zwiększą prawdopodobieństwo, że zastosowanie danej procedury będzie skuteczne dla jego pacjentów, którzy są zróżnicowani i mogą borykać się z wieloma dolegliwościami jednocześnie. Stąd powstaje pytanie, czy badania nieuwzględniające tak dużej zmienności w obrębie grup spełniają wymogi trafności zewnętrznej (Worall 2010: 361).

Promowanie konkretnych metod akumulowania wiedzy, wymóg przeprowadzania krytycznej analizy uzyskiwanych dowodów oraz sprecyzowane techniki ich wykorzystania wskazują, że postulowana przez zwolenników EBM zmiana paradygmatu w medycynie polega przede wszystkim na jej znormalizowaniu.

\section{EKSPERTYZA KLINICZNA}

Aby uporządkować wywód, ograniczę kwestię przebiegu rozumowań lekarskich do etapu diagnostycznego. W tym kontekście ponownie powołam się na Guyatta i współpracowników z Grupy Roboczej EBM, podkreślających wa- 
gę ekspertyzy klinicznej dla prawidłowego przebiegu procesu diagnostycznego. Umiejętności krytycznej oceny dowodów i zrozumienie metod ilościowych w medycynie wlicza się jako skutki treningu - obok doświadczenia klinicznego - w obręb ekspertyzy. W całości ekspertyza umożliwia przeprowadzenie rozumowania klinicznego opartego na dowodach (evidence-based reasoning) i „włączającego wskaźniki prawdopodobieństw” (Guyatt i in. 2000: 1293). Henrik R. Wulff oraz Peter C. Gøetzsche stwierdzają wprost, że „nie ma najmniejszej wątpliwości, że dobry diagnosta [...] jest ekspertem w myśleniu bayesowskim" (Wulff, Gøetzsche 2005: 123). Potwierdza to opinia Davida Sacketta podkreślającego konieczność integrowania doświadczenia klinicznego $\mathrm{z}$ wiedzą epidemiologiczną i biostatystyczną. $\mathrm{W}$ tym duchu wypowiadają się również inni propagatorzy nurtu EBM (Switzer, Horton 2007: 17-21). Pojawia się więc teza, że lekarz powinien rozumować zgodnie z twierdzeniem Bayesa i aksjomatyką Kołmogorowa. Newralgiczna w działalności lekarza jest więc znajomość pojęć statystycznych. Lekarz praktykujący w nurcie EBM określa miarę prawdopodobieństwa przed testem (pre-test probability $\mathrm{P}_{\text {prior}}$ ), znając częstość występowania danej choroby w określonej populacji (prevalence), a wielkość prawdopodobieństwa po teście (post-test probability $-\mathrm{P}_{\text {post }}$ ), uwzględniając swoistość (specificity) oraz czułość (sensitivity) testu diagnostycznego. Swoistość, czyli prawdopodobieństwo uzyskania negatywnego wyniku testu pod warunkiem, że pacjent nie cierpi na schorzenie, oraz czułość, czyli prawdopodobieństwo uzyskania pozytywnego wyniku testu pod warunkiem, że pacjent cierpi na schorzenie, są obok innych pojęć statystycznych podstawowe dla wiarygodnej diagnozy i właściwej informacji dla pacjenta3.

Testy diagnostyczne i dodatkowe badania przedmiotowe dostarczają lekarzowi materiału do wzmacniania lub osłabiania jego uprzednich założeń na temat stanu pacjenta. Jest to modyfikacja w obrębie przyjmowanych przez lekarzy miar prawdopodobieństwa wystąpienia danej choroby przy określonych objawach oraz wynikach badań. Wprowadzenie tej modyfikacji odbywa się przy zastosowaniu twierdzenia Bayesa w postaci:

$$
P(H \mid E)=\frac{P(E \mid H) \cdot P(H)}{P(E)}
$$

3 Test diagnostyczny może dać jeden z czterech rodzajów wyników: prawdziwie dodatni, fałszywie dodatni, prawdziwie ujemny oraz fałszywie ujemny. Oprócz czułości i swoistości ważne w tym kontekście są również pojęcia wartości predykcyjnej wyniku dodatniego (positive predictive value) i wartości predykcyjnej wyniku ujemnego (negative predictive value). 
gdzie $\mathrm{P}(\mathrm{H})$ - prawdopodobieństwo a priori zachodzenia hipotezy $\mathrm{H}, \mathrm{P}(\mathrm{E})-$ prawdopodobieństwo otrzymania dowodu, a pionowa kreska (x|y) to symboliczne określenie funktora „x pod warunkiem, że y”. Prawdopodobieństwo jest rozumiane jako funkcja ze zbioru zdarzeń $\mathrm{w}$ zbiór wartości $\mathrm{z}$ przedziału $<0,1>$. Po zastosowaniu twierdzenia o prawdopodobieństwie całkowitym otrzymujemy:

$$
P(H \mid E)=\frac{P(E \mid H) \cdot P(H)}{P(E \mid H) \cdot P(H)+P(E \mid \neg H) \cdot P(\neg H)}
$$

Po prawej stronie kreski warunkowej znajduje się zdarzenie, którego zachodzenie jest faktem. Jest to założenie. Na tej podstawie określa się, z jaką szansą zachodzi zdarzenie, o którym mowa po lewej stronie kreski.

Informacje uzyskiwane przez lekarza $\mathrm{w}$ procesie diagnozowania tworzą diagnostyczny profil pacjenta rozumiany jako zbiór możliwych rozpoznań chorób zgodnych z danymi objawami. Profil ten stanowi podstawę diagnostyki różnicowej (differential diagnosis) obejmującej analizę hipotez dotyczących stanu pacjenta formulowanych na podstawie jego profilu diagnostycznego (Miettinen 2001: 781-782). Te konkurencyjne hipotezy mogą zachodzić z pewnym prawdopodobieństwem. Profil diagnostyczny kształtuje zatem specyficzny dla konkretnego pacjenta rozkład prawdopodobieństw. W ustaleniu tego rozkładu pomocne jest twierdzenie Bayesa. Lekarz w trakcie wywiadu z pacjentem i badań przedmiotowych (np. osłuchiwania czy badań palpacyjnych) zbiera dane, które stanowią podstawę do formułowania pierwszych hipotez o określonym prawdopodobieństwie zachodzenia. Zaordynowanie testów diagnostycznych odpowiednich dla pierwotnych przewidywań diagnosty wiąże się już z zaangażowaniem narzędzi, których skuteczność musi zostać udowodniona, zanim dojdzie do ich wykorzystania. Czułość i swoistość testu ingerują $\mathrm{w}$ proces właśnie $\mathrm{w}$ tym miejscu. $\mathrm{W}$ literaturze przedmiotu odnajdujemy wiele głosów za tym, że inaczej być nie może, jeśli pragnie się uzyskać wiarygodną diagnozę lekarską (Davidoff 1999).

Istnieją jednak przesłanki wskazujące, że w procesie diagnostycznym lekarze uciekają się do zupełnie innych metod rozumowania. Pat Croskerry (2002) wskazuje cztery z nich. Pierwsza to rozpoznawanie wzorca (pattern recognition). Zgodnie $\mathrm{z}$ nią lekarz poszukuje $\mathrm{w}$ objawach pacjenta znanych mu schematów. Przebiega to w dwóch trybach. Przetwarzanie typu bottom-up oraz top-down to terminologia neurobiologiczna sensu stricto odwołująca się do teorii dwutorowego przetwarzania informacji (dual-track processing). Przetwarzanie bodźców przez ludzki układ nerwowy może przebiegać w sposób planowy, gdy mamy do czynienia z przetwarzaniem wcześniejszej wiedzy lub ustalonego schematu postępowania (top-down), bądź automatyczny, gdy 
mamy do czynienia z wewnętrznymi własnościami bodźca, na przykład niespodziewanym błyskiem światła (bottom-up) (Buschman, Miller 2007: 1860). Objawy pacjenta nakierowują lekarza na diagnozę w trybie bottom-up. Pojedyncze symptomy chorobowe mogą mówić mu niewiele, lecz zebrane w zespół tworzą konkretny obraz kliniczny, który następnie odnoszony jest do obrazów klinicznych znanych lekarzowi. To już przetwarzanie w trybie top-down.

Drugą metodę rozumowania Croskerry nazywa wykluczeniem najgorszych scenariuszy. Lekarz ma dostęp do wiedzy na temat patofizjologii chorób. Zapoznając się z danymi objawami, rozważa wzorce chorób mogących je powodować. Metoda ta polega na wykluczeniu skrajnych hipotez odpowiadających wzorcom i zawężeniu tym samym pola poszukiwań. Trzecia metoda - nieoptymalna - polega na wyczerpującym przeszukiwaniu danych (exhaustive strategy). Może ona być typowa dla młodych czy dopiero rozpoczynających praktykę lekarzy stawiających czoła sytuacji niepewności. Poszukiwanie danych klinicznych odbywa się wtedy w sposób nieselektywny i bez hierarchizacji informacji. W języku teorii gier powiedzielibyśmy, że w tej strategii wykorzystywana jest zasada nieodróżnialności (indifference rule) polegająca na przypisaniu wszystkim możliwościom tej samej miary prawdopodobieństwa.

Ostatnia metoda opisywana przez Croskerry'ego jest odwrotnością rozpoznawania wzorca. Pierwszym etapem przetwarzania danych jest tryb top-down, w którym formułowane są możliwe hipotezy na temat stanu pacjenta. Następnie w przetwarzaniu bottom-up poszukiwane są przyczyny danego stanu przy jednoczesnym uzgadnianiu ich z pozyskiwanymi przez lekarza danymi oraz hipotezami. Jest to metoda hipotetyczno-dedukcyjna (hypothetico-deductive method). Wulff i Gøetzsche (2005: 92) nazywają ją po prostu „podejściem dedukcyjnym". Bardzo możliwe, że to właśnie ona jest wyróżnikiem działań „starej szkoły” w medycynie. Lekarz wychodzi tu od założeń czynionych w stosunku do formułowanych hipotez. Dopiero w kolejnym kroku dokonuje oceny pozyskiwanych informacji. Zdaniem Franka Davidoffa (1999) jest to postawienie właściwego sposobu rozumowania klinicznego na głowie. Przemawia on oczywiście z pozycji praktyka EBM.

\section{PODEJŚCIE NORMATYWNE I DESKRYPTYWNE DO DECYZJI KLINICZNYCH}

W świetle teorii decyzji diagnoza stanowi pewien typ problemu decyzyjnego. Wyróżnia się trzy typy decyzji: decyzje $\mathrm{w}$ warunkach pewności, gdzie każde działanie decydującego prowadzi do określonego i znanego wyniku, de- 
cyzje w warunkach ryzyka, gdzie każdemu możliwemu działaniu przypisany jest rozkład prawdopodobieństwa wystąpienia określonego wyniku ze zbioru wyników możliwych, oraz decyzje w warunkach niepewności. Te ostatnie podejmowane są bez znajomości rozkładów prawdopodobieństwa wystąpienia odpowiednich wyników (Grzybowski 2012: 16).

W literaturze przedmiotu istnieje zgoda co do tego, że problemy decyzyjne w działalności lekarskiej należą do trzeciego typu (Wolf, Gruppen, Billi 1985: 2858). Nie jest to sytuacja komfortowa dla lekarza. W teorii gier wskazuje się wiele możliwych strategii, które może przyjąć gracz w sytuacji niepewności. Mogą być one jednak odmienne od tych przypisywanych działaniom lekarskim. Nie podejmując zatem próby modelowania decyzji lekarskich aparaturą pojęciową teorii gier (choć pojawią się tu jeszcze odwołania do teorii gier i decyzji), zaryzykuję twierdzenie, że formowanie profilu diagnostycznego specyficznego dla konkretnego pacjenta umożliwia przejście od sytuacji niepewności do sytuacji ryzyka. Stąd też właściwą metodą podejmowania decyzji lekarskich jest zastosowanie twierdzenia Bayesa. Zapewnia to uzyskanie rozkładów prawdopodobieństwa dla możliwych do podjęcia decyzji diagnostycznych i terapeutycznych. Nazywa się to normatywnym podejściem do decyzji lekarskich. Wskazałem jednak wyżej, że lekarze posługują się również innymi strategiami działania, dalekimi od modelu normatywnego. Tak więc analizę strategii decyzyjnych stosowanych przez lekarzy w warunkach rzeczywistych określa się jako podejście deskryptywne (dla odróżnienia od podejścia normatywnego). Od teraz w odniesieniu do metod podejmowania decyzji klinicznych będę się posługiwał głównie tymi dwoma ogólnymi kategoriami.

Podział na podejście deskryptywne i normatywne przy charakterystyce decyzji lekarskich jest kojarzony przez niektórych z podziałem na decyzje nieracjonalne i racjonalne. $\mathrm{W}$ doniesieniach medialnych co jakiś czas pojawiają się rewelacje o tym, że lekarze nie znają podstawowych pojęć statystycznych, które powinny być podstawą decyzji specjalistycznych (por. np. Cieślińska 2014). Tym samym dokonuje się osądu właśnie na temat poziomu racjonalności tych decyzji.

W rozważaniach na temat związku między aspektami normatywnym i deskryptywnym decyzji oraz kryteriami racjonalności decyzji pomocna jest terminologia wypracowana przez Keitha Stanovicha (Stanovich, West 2000). Jego zdaniem między podejściem deskryptywnym a normatywnym istnieje rozziew (gap).

Teorie decyzji proponują konkretne zasady postępowania w obliczu problemów decyzyjnych. Przykładowo, w ramach teorii wartości oczekiwanej decydent w obliczu dylematu między możliwościami: (a) wygrana 100 zł z szansą 50\% i (b) wygrana $100 \mathrm{zł} \mathrm{z} \mathrm{szansą} \mathrm{60 \%} \mathrm{powinien} \mathrm{wybrać} \mathrm{zakład} \mathrm{(b).}$ 
Wartość oczekiwana możliwości (b) jest bowiem wyższa niż (a), co wynika z prostego obliczenia $(100 \times 0,6>100 \times 0,5$, a więc (b) $>$ (a)). Zgodnie z teorią wartości oczekiwanej racjonalny decydent, który ma dostęp do informacji o wielkości wypłat i prawdopodobieństw ich otrzymania przy poszczególnych możliwościach, powinien być w stanie określić, która z możliwości daje większą wypłatę i to właśnie ją wybrać. Doświadczenie pokazuje jednak, że tak nie jest. Badania ekonomistów i psychologów behawioralnych od pół wieku ukazują rozbieżności między rzeczywistymi sposobami podejmowania decyzji a tymi zalecanymi przez różnego rodzaju teorie. Właśnie tę niezgodność Stanovich nazywa rozziewem.

W badaniach rozziew obrazowany jest za pomocą wielkości błędów popelnianych w pewnych zadaniach logicznych lub zakładach podobnych do opisanego wyżej4. Duża liczba odpowiedzi niezgodnych z odpowiedzią uznawaną przez badaczy za poprawną eliminuje wpływ przypadkowych omyłek na wyniki. Na tej podstawie mówi się o systematycznych błędach, co następnie odnosi się do ocen poziomu racjonalności decyzji podejmowanych przez ludzi. Okazuje się, że błędy występują na tyle często, że zaczęto się zastanawiać, czy można w ogóle mówić o racjonalności podejmowanych decyzji. Wymaga to zatem wyjaśnienia.

Stanovich stwierdza, że istnieją cztery sposoby wyjaśniania rozziewu. Po pierwsze, ludzie decydują niezgodnie z modelem normatywnym ze względu na tymczasowe deficyty uwagi, czujności lub pamięci. Po drugie, zasoby poznawcze i zdolności obliczeniowe człowieka są z zasady ograniczone, a więc nie zawsze ma on możliwość dokonania rzetelnej oceny sytuacji i podjęcia właściwej (w sensie normatywnym) decyzji. Po trzecie, problem może wynikać z zastosowania niewłaściwego modelu normatywnego do danego problemu decyzyjnego. Wreszcie, możliwe, że ludzie rekonstruują problem na swój sposób, a model normatywny dobierają adekwatnie do interpretacji, podczas gdy na poziomie analizy rozwiązań przyjętych przez podmioty podejmujące decyzje zostaje dobrany inny model, nieadekwatny do przyjętej przez nich interpretacji.

Pomysł samego Stanovicha na wyjaśnienie rozziewu odwołuje się do teorii dwutorowego przetwarzania informacji. Wyróżnia on dwa systemy poznawcze - System 1 i System 2. Różnica między nimi polega na odmiennym rekonstruowaniu zadań, którym próbuje sprostać ludzki mózg (Stanovich, West 2000: 646-659). System 1, oparty na płytkim przetwarzaniu informacji, rozwiązuje zadania osadzone $\mathrm{w}$ aktualnym kontekście, stąd postępuje szybko i automatycznie. System 2, wymagający przetwarzania głębokiego, abstrahuje

${ }_{4}^{4}$ Mowa tutaj o zadaniach takich jak Test Selekcji Wasona lub tzw. Problem Lindy. 
od kontekstu, kieruje się ogólnymi normami i zasadami, dlatego pochłania więcej uwagi i czasu. Rozdźwięk między podejściem normatywnym a deskryptywnym wynika z różnych stopni zaangażowania zasobów poznawczych ludzkiego mózgu.

Pionierami badań nad rzeczywistym przebiegiem procesów decyzyjnych są m.in. Amos Tversky i Daniel Kahneman, którzy w 1974 r. opublikowali artykuł poświęcony sądom w warunkach niepewności. Stwierdzają, że ludzie opierają swoje przewidywania na mechanizmach redukujących złożone zadania do zadań prostszych, czyli na heurystykach. W 2011 roku Kahneman, już na własną rękę, usystematyzował prawie 40 lat badań nad tym zagadnieniem. Wykorzystał także kategorie Systemu 1 i Systemu 2. Heurystyki definiuje jako procedurę umożliwiającą uzyskanie skutecznych, choć nieprecyzyjnych rozwiązań złożonych problemów (Kahneman 2012: 133). Istnieją trzy mechanizmy poznawcze skłaniające nas do zastosowania heurystyk. Pierwszy to mechanizm zastępowania (substitution) pytania właściwego, trudniejszego prostszym pytaniem heurystycznym. Drugi mechanizm to „umysłowe strzelanie śrutem”, czyli nieumiejętność precyzyjnego dopasowania odpowiedzi do pytania właściwego. Trzeci wreszcie to dopasowanie intensywności, czyli subiektywne skwantyfikowanie możliwych odpowiedzi na pytanie heurystyczne i dostosowanie ich do pytania właściwego. Wszystkie miałyby wywodzić się z funkcji Systemu 1.

Wyobraźmy sobie osobę postawioną przed pytaniem o prawdopodobieństwo wyrzucenia szóstki na kostce do gry i wygranej. Może w ogóle nie znać pojęcia prawdopodobieństwa, a mimo to udzielić poprawnej odpowiedzi, ponieważ może starać się odpowiedzieć na prostsze pytanie heurystyczne dotyczące jej przekonań na temat poziomu swojego szczęścia (mechanizm zastępowania). Może też uznać, że jest wyjątkowym szczęściarzem. Odpowiedź ta nie ma nic wspólnego z pytaniem właściwym (mechanizm „umysłowego strzelania śrutem”). Podejmujący decyzję umieści jednak kategorię „bycia szczęściarzem" na szczycie skali intensywności, którą posługuje się jako ekwiwalentem skali miary prawdopodobieństwa (mechanizm dopasowania skali intensywności). W ten sposób może dojść do wniosku, że prawdopodobieństwo wypadnięcia szóstki, a zatem i wygranej, jest wysokie. Jeśli szóstka rzeczywiście wypadnie i nasz bohater wygra, to prawdopodobnie utwierdzi się w przekonaniu, że jego strategia rozumowania jest poprawna.

Tak rozumiane heurystyki będę nazywał Kahnemanowskimi. Dzięki nim osoba podejmująca decyzję z dużą łatwością znajduje rozwiązanie potencjalnie trudnego problemu. Poza tą niewątpliwą zaletą heurystyki mają według Kahnemana jednak pewną zasadniczą wadę: prowadzą do systematycznych błędów. W końcu bohater naszego przykładu nie odpowiedział na pytanie 
o miarę prawdopodobieństwa, lecz na pytanie o ocenę swojego poziomu szczęścia. Było to wynikiem automatycznego Systemu 1 - uniknięcie jego mechanizmów wymagałoby zaangażowania kosztowniejszych mechanizmów Systemu 2. Przy tak sformułowanej definicji heurystyki widać, w jaki sposób Kahneman interpretuje teorię dwutorowego przetwarzania informacji. Kładzie nacisk na to, w jakim stopniu podejmujący decyzję kontroluje przebieg procesu wnioskowania przy aktywności mechanizmów Systemu 1 i Systemu 2. Przez lata Tversky i Kahneman przeprowadzali badania pokazujące, że mamy naturalną skłonność ulegania niekontrolowanym mechanizmom Systemu 1 odwracającym uwagę od normatywnych modeli decyzyjnych (Tversky, Kahneman 1973, 1981, 1986). Należy im więc przypisać dużą zasługę w powiązaniu niekontrolowalnych aspektów procesów poznawczych człowieka (System 1) z pojęciem nieracjonalności.

Lekarze na co dzień pracują $\mathrm{w}$ warunkach niepewności. Dużą w tym rolę odgrywa przeładowanie informacyjne utrudniające wyselekcjonowanie i przetworzenie wszystkich ważnych danych przez specjalistę (West, West 2002). Croskerry (2002: 1185) dodaje, że w niektórych specjalnościach w trakcie swojej zmiany lekarz musi podjąc „tysiące decyzji” przy ograniczeniach czasu, zasobów i wytrzymałości. Są to warunki sprzyjające posługiwaniu się heurystykami.

Wiele badań wskazuje, że tak jest i lekarze rzeczywiście posługują się uproszczonymi sposobami rozumowania (Blumenthal-Barby, Krieger 2015). Donald Redelmeier i Eldar Shafir przeprowadzili wśród kanadyjskich lekarzy rodzinnych badanie ankietowe sprawdzające zgodność stosowanych przez nich procedur decyzyjnych $\mathrm{z}$ założeniami normatywnej teorii użyteczności. Dwie grupy lekarzy rodzinnych z Ontario otrzymały ankiety, w których poproszono ich o podjęcie decyzji, czy przepisaliby pacjentowi cierpiącemu na chroniczny ból zwyrodnieniowy stawu lek przeciwbólowy, którego wcześniej nie próbowal. Hipotetyczny pacjent przyjmował wcześniej leki przeciwzapalne, lecz okazały się one nieskuteczne. W pierwszej grupie lekarze mieli podjąć decyzję, czy podadzą ibuprofen, czy też nie zalecą żadnych środków. W drugiej natomiast do dyspozycji mieli dwa rodzaje leków przeciwzapalnych. Decydowali między ibuprofenem i piroxicamem z możliwością zaniechania zaordynowania któregokolwiek z leków. Okazało się, że lekarze częściej nie przepisywali żadnego leku w grupie drugiej niż w pierwszej (Redelmeier, Shafir 1995). Postawieni przed dylematem lekarze woleli wybrać trzecią odpowiedź - możliwość odstąpienia od decyzji. Wskazuje to na lekceważenie własności relacji preferencji przewidywanych przez teorię oczekiwanej użyteczności5 i tym samym na rozziew między podejściem deskryptywnym

5 Teoria oczekiwanej użyteczności posługuje się pojęciem użyteczności jako subiektyw- 
a normatywnym w decyzjach podejmowanych przez lekarzy. Bez względu na pojawienie się dodatkowej możliwości, jeśli lekarze przedkładają przepisanie jakiegoś leku (ibuprofen) nad nieprzepisywanie żadnego, kierunek relacji preferencji powinien zostać zachowany, mimo pojawienia się trzeciej możliwości (piroxicamu).

Redelmeier i Shafir dają pewne porady co do tego, jak pozbyć się rozziewu. Klinicyści powinni poznać rodzaje błędów zagrażających poprawności ich osądów i szkolić się w metodach ich korygowania. Co do zasady zgadza się z nimi Arthur Elstein (1999) zwracający uwagę na ograniczenia ludzkiego aparatu poznawczego. Wśród innych ekspertów również panuje zgoda co do tego, że niezbędna jest kompleksowa edukacja statystyczna lekarzy (Kuklin 2006, Monahan 2007). Ian Kestin stwierdził wręcz, że „wszyscy klinicyści powinni rozumieć, w jaki sposób poprawnie obchodzić się z danymi badawczymi” (Kestin 2015: 200). Ta powinność stanowi podstawę krytyki praktyki lekarskiej odbiegającej od normatywnego standardu, zgodnie z zasadą „skoro się uczyl, to powinien wiedzieć". Zauważmy jednak, że myślenie o deskryptywnym podejściu do rozumowań lekarskich zostało zdominowane przez Kahnemanowskie ujęcie heurystyk. Ryzyko opierania się na nich stało się probierzem, dzięki któremu z latwością określa się, jakie postępowanie lekarskie jest racjonalne, a jakie nie. Warto jednak podkreślić, że jakkolwiek edukacja (bio)statystyczna lekarzy jest ważna, to nie może stanowić jedynej podstawy oceny tego, w jaki sposób przebiega proces diagnozy. Bądź co bądź niezbywalnym elementem praktyki lekarskiej jest jej skuteczność. Uznanie, że tylko diagnoza wydana $\mathrm{z}$ wykorzystaniem twierdzenia Bayesa jest racjonalna, może prowadzić do sytuacji absurdalnych.

W literaturze przedmiotu lekarze z niepokojem wypowiadają się o stosowaniu heurystyk w praktyce klinicznej. Dużą zasługę ma w tym Kahnemanowskie ujęcie heurystyk. Wykorzystane $\mathrm{w}$ nim rozróżnienie między mechanizmami Systemu 1 i Systemu 2 sprawia wrażenie powiązania opozycji niekontrolowane-kontrolowane z opozycją nieracjonalne-racjonalne. Heurystyki miałyby stanowić wyraz niekontrolowanych procesów umysłu prowadzących do nieracjonalnych rozwiązań i opartych na nich decyzji. W świetle debaty nad teoriami dwutorowego przetwarzania informacji prowadzi to jednak do pojęciowego zamętu. Po pierwsze, nie istnieje zgoda co do tego, w jakie relacje wchodzą własności przypisywane obu systemom. Stanovich przekonywał, że nie trzeba identyfikować wszystkich własności przypisywanych na przykład Systemowi 1, by mówić o zachodzeniu procesów tego właśnie

ną miarą korzyści osoby decydującej. Opiera się zatem na relacji preferencji charakteryzującej się pewnymi własnościami. Dzięki nim możliwe jest wykreślenie funkcji użyteczności decyzji dla osoby ją podejmującej. 
systemu (Stanovich, Toplak 2012). Ponadto, biorąc pod uwagę poziom zaawansowania badań nad procesami decyzyjnymi człowieka, niefortunne wydaje się potraktowanie kategorii racjonalności jako własności decyzji. Konsekwencją tego byłaby możliwość sprawdzenia stopnia korelacji między, na przykład, poziomem kontroli mechanizmów poznawczych z poziomem racjonalności wynikłych stąd decyzji. Problem polega jednak na tym, jak stwierdzić, że decyzja jest racjonalna, a nie na tym, jak racjonalność odnieść do innych zjawisk procesu decyzyjnego człowieka. Po drugie, w psychologii debata nad teoriami dwutorowego przetwarzania informacji toczy się właściwie między zwolennikami stanowisk poznawczego i ewolucjonistycznego (Evans 2003). Przełożenie jej rozstrzygnięć na zagadnienia procesów decyzyjnych niekoniecznie jest proste. Warto zauważyć, że metody podejmowania decyzji badane są za pomocą zadań logicznych lub zakładów. $\mathrm{Z}$ zasady zatem zredukowane $\mathrm{w}$ nich zostaje znaczenie kontekstu niezbywalnego przecież $\mathrm{w}$ codziennych sytuacjach decyzyjnych w środowisku medycznym.

\section{ZAMIESZANIE W PODEJŚCIACH}

O uwzględnienie szerokiego kontekstu rzeczywistych sytuacji decyzyjnych od lat zabiega Gerd Gigerenzer. Nie przecząc dokonaniom Tversky'ego i Kahnemana, zwraca uwagę na niedoskonałości ich koncepcji heurystyk. Według Gigerenzera za pomocą pojęcia heurystyki można wyjaśnić każde ludzkie zachowanie, nie wymaga się przy tym powiedzenia czegokolwiek na temat głębszych mechanizmów jej działania. Jest to wynikiem, po pierwsze, niejasności pojęcia heurystyki (vague heuristics), a po drugie, odwołania się do norm adekwatnych dla małego zbioru zdarzeń (narrow norms) (Gigerenzer 1996: 592). Stosując model heurystyk w ujęciu Kahnemanowskim, można stwierdzić tylko, że ostateczna decyzja podjęta przez daną osobę jest inna niż zakładana przez normę. Dopuszcza to wielorakość interpretacji takiej obserwacji (porównywaną przez Gigerenzera do interpretacji plam Rorschacha), ponieważ nieznany pozostaje mechanizm postulowanej heurystyki. Wiadomo jedynie, że normy lekceważone przy wykorzystaniu heurystyk są interpretowane jako uniwersalne. Gigerenzer sprzeciwia się jednak takiemu stawianiu sprawy. Norma może bowiem, na przykład, wymagać zastosowania pojęcia prawdopodobieństwa odpowiedniego dla zdarzeń pojedynczych (subiektywnego), choć okoliczności wymagają, by użyć pojęcia odpowiedniego dla serii zdarzeń (częstościowego). Normy zakładane w heurystykach okazują się nie- 
wrażliwe na kontekst ich wykorzystania, stając się treściowo obojętne (content-blind) wobec warunków rzeczywistych, dla których treść jest istotna.

Gigerenzer uznał, że o wartości eksplanacyjnej heurystyk świadczy ich czułość na okoliczności, w których są stosowane. W tym ujęciu, jeśli heurystyki zinterpretuje się jako strategie kierujące przebiegiem rozumowania osoby podejmującej decyzję, mogą stać się podstawą do rekonstruowania modelu predykcyjnego wykorzystanego przez decydującego w danej sytuacji. Tak rozumiane heurystyki będę nazywał Gigerenzerowskimi.

Wykorzystanie heurystyk Kahnemanowskich w charakterze wyjaśniania rozumowań wiąże się z przekonaniem, że trafność przewidywań jest wprost proporcjonalna do ilości czasu i wysiłku poświęconych analizie dostępnych danych. Poleganie na mniej kosztownych heurystykach miałoby się wiązać z mniejszą trafnością przewidywań. Gigerenzer i Henry Brighton nazwali to kompromisem między trafnością a wysiłkiem (accuracy-effort trade-off). Przekonują, że jest to przekonanie błędne, a z ich badań wynika wręcz, że stosowanie heurystyk nie tylko oszczędza czas i wysiłek, lecz także pozwala na uzyskanie lepszej trafności niż tradycyjne modele predykcyjne. Kompromisowi między trafnością a wysiłkiem przeciwstawili efekt „mniej za więcej” (less-is-more effect), zgodnie z którym większe koszty analizy danych wiążą się ze zmniejszeniem trafności przewidywań (Gigerenzer, Brighton 2009: 110). Istnieją badania pokazujące, że modele wykorzystujące większą ilość informacji prowadzą do większej liczby błędów niż proste strategie posługujące się mniejszą ilością danych (Gigerenzer, Gaissmaier 2011: 455). Ma na to wpływać mniejsze rozproszenie danych wokół średniej (wariancja) w modelach predykcyjnych opartych na prostych strategiach. Jest to rdzeń mechanizmu działania heurystyk w ujęciu Gigerenzerowskim. Dzięki zignorowaniu części dostępnych informacji, czyli w założeniu tzw. szumu informacyjnego, strategie heurystyczne mają zapewniać korzystniejszy stosunek trafności do wysiłku, uwzględniać ograniczenia poznawcze ludzkiego mózgu oraz okoliczności (środowiska), w których przeprowadzane jest rozumowanie.

W najogólniejszej formie heurystyki Gigerenzerowskie ksztaltowane są przez trzy elementy: regułę przeszukiwania informacji, regułę zaprzestania poszukiwań i regułę powzięcia decyzji. Analiza przeprowadzonego procesu decyzyjnego musi się zatem rozpocząc od określenia sposobu, w jaki został sformułowany problem decyzyjny, i bezwzględnie odwoływać się do okoliczności (środowiska) wystąpienia problemu. Strategie heurystyczne Gigerenzera prowadzą jednak do czegoś więcej - do zupełnie innego ujęcia racjonalności. Heurystyki te ignorują bowiem część dostępnych danych, lecz włączają $\mathrm{w}$ proces decyzyjny informacje o dostępnych $\mathrm{w}$ środowisku zasobach - poznawczych, czasowych itp. Kompromis następuje zatem nie na poziomie wy- 
siłku wkładanego w procedurę wnioskowania, lecz na poziomie dostępności zasobów niezbędnych do przeprowadzenia wnioskowania w danych warunkach. Heurystyki Gigerenzerowskie stają się racjonalne przez to, że same wytwarzają model normatywny, którym kieruje się decydent. Do odróżnienia podejścia deskryptywnego od normatywnego niezbędne jest założenie norm zewnętrznych wobec podatnych na opis procesów rozumowania. $\mathrm{W}$ ujęciu Gigerenzera jedno zlewa się z drugim, eliminując samo rozróżnienie. W konsekwencji znika także rozziew decyzyjny ${ }^{6}$.

Ma to zasadnicze znaczenie dla zagadnienia rozumowań $\mathrm{w}$ procesie diagnostycznym. Odette Wegwarth wraz z zespołem porównała skuteczność strategii opartej na wykazach miar prawdopodobieństw zajścia pewnych zdarzeń klinicznych i strategii heurystycznej opartej na tzw. drzewach decyzyjnych. Strategia ta polega na rozbiciu głównego problemu na jego składowe ujmowane w węzły decyzyjne. W zależności od odpowiedzi („tak” lub „nie”) podejmujący decyzję przechodzi przez kolejne węzły, docierając w końcu do rozstrzygnięcia pierwotnego problemu decyzyjnego.

Wegwarth, Gassmaier, Gigerenzer (2009) podają przykład Szpitala Uniwersyteckiego w Michigan, gdzie wystąpił problem przyjmowania nadmiernej liczby pacjentów na oddział kardiologiczny z podejrzeniem zawału serca. Okazało się, że jedynie $25 \%$ przyjętych rzeczywiście przechodziło zawał. Tak duży zakres błędu predykcyjnego jest dla szpitala dużym obciążeniem. Opracowano zatem narzędzie mające ułatwić lekarzom przewidzenie wystąpienia zawału u pacjenta. Była to karta informacyjna z wypisanymi objawami zawału oraz procentowo opisanymi miarami prawdopodobieństwa, że dana osoba rzeczywiście przechodzi zawał, mając charakterystyczny dla niego zespół objawów. Zatem lekarze korzystający z tego narzędzia musieli skwantyfikować objawy pacjenta i obliczyć szansę wystąpienia zawału. Skuteczność karty była stosunkowo wysoka - w większości przypadków pacjentów przechodzących zawał diagnozowano poprawnie. Wysoki był jednak także wskaźnik błędu, ponieważ na oddział wciąż przyjmowano wielu pacjentów, którzy zawału nie przechodzili. Drzewo decyzyjne polega natomiast na zignorowaniu prawdopodobieństw wystąpienia poszczególnych zdarzeń dla obrazu klinicznego zawału i przechodzeniu od jednego węzła decyzyjnego do kolejnego, udzielając odpowiedzi na zamknięte pytania, na przykład czy wykres badania EKG jest spłaszczony na odcinku ST. Skuteczność drzewka okazała się wyższa niż karty informacyjnej przy jednoczesnym znacznym zmniejszeniu błędu predykcyjnego (Wegwarth, Gassmaier, Gigerenzer 2009).

\footnotetext{
${ }^{6}$ Warto dodać, że Gigerenzer odżegnuje się od teorii dwutorowego przetwarzania informacji. Umieszczając heurystyki wśród strategii decyzyjnych, nie wikła się także w odróżnienie procesów kontrolowanych od niekontrolowanych.
} 


\section{PODSUMOWANIE}

Istnieje rozdźwięk między deskryptywnym podejściem do decyzji lekarskich a podejściem normatywnym wynikającym z założeń evidence-based medicine. Twierdzenie o niezgodności między pierwszym a drugim zakłada jednak dwutorową teorię przetwarzania informacji, która przyjmuje, że System 1 odpowiada za procesy zautomatyzowane, a więc niepodlegające świadomej kontroli, a System 2 za procesy deliberatywne, w znacznej mierze podlegające kontroli. Popularyzacja badań nad heurystykami w ujęciu Kahnemanowskim doprowadziła do przypisania Systemowi 1 etykiety mechanizmów prowadzących do decyzji nieracjonalnych. Racjonalność decyzji wiązana jest z procesami Systemu 2, co w przypadku klinicystów sprowadza się do rozumienia narzędzi statystycznych i wykorzystania ich w praktyce klinicznej.

Badania Gigerenzera nad strategiami heurystycznymi pokazują jednak, że racjonalność nie jest pojęciem jednowymiarowym i nie można jej utożsamiać $\mathrm{z}$ postępowaniem zgodnym $\mathrm{z}$ abstrakcyjnymi normami. Modelowanie strategii heurystycznych ujawnia ukryte założenia stojące za rozróżnieniem między deskryptywnością a normatywnością. Okazuje się bowiem, że rozziew deskryptywno-normatywny wcale nie musi być tak przepastny, a być może w ogóle nie istnieje. Rozwój badań nad heurystykami Gigerenzerowskimi zmniejsza ciężar kierowanego pod adresem lekarzy zarzutu nieracjonalności. Heurystyki Kahnemanowskie, z których korzystanie w rozumowaniach klinicznych wstrząsnęło światem medycyny, nie muszą wskazywać, że dzieje się coś niewłaściwego. Ostatecznie medycyna coraz lepiej spełnia swoje zadania. To heurystyki Kahnemanowskie nie uwzględniają specyfiki warunków klinicznych i wymuszają włączenie standardów teoriodecyzyjnych spoza medycyny do praktyki lekarza.

\section{BIBLIOGRAFIA}

Abel U., Koch A. (1999), The Role of Randomization in Clinical Studies. Myth and Beliefs, „Journal of Clinical Epidemiology” 52(6), 487-497.

Blumenthal-Barby S. J., Krieger H. (2015), Cognitive Biases and Heuristics in Medical Decision Making. A Critical Review Using a Systematic Search Strategy, „Medical Decision Making” 35(4), 539-557.

Buschman J. T., Miller K. E. (2007), Top-Down versus Bottom-Up Control of Attention in the Prefrontal and Posterior Cortices, „Science” 315(5820), 1860-1862.

Chalmers I. (1993), The Cochrane Collaboration. Preparing, Maintaining, and Disseminating Systematic Reviews of the Effects of Health Care, „Annals of the New York Academy of Sciences" 703(1), 156-165. 
Cieślińska I. (2014), Nieznajomość matematyki zabija [w:] „Gazeta Wyborcza” 21.11.2014, https://bit.ly/2BDyHaL.

Croskerry P. (2002), Achieving Quality in Clinical Decision Making. Cognitive Strategies and Detection of Bias, „Academic Emergency Medicine Journal” 9(11), 1184-1204.

Davidoff F. (1999), Standing Statistics Right Side Up, „Annals of Internal Medicine” 130(12), 1019-1021.

Davidoff F., Haynes B., Sackett D., Smith R. (1995), Evidence Based Medicine. A New Journal to Help Doctors Identify Information They Need, „British Medical Journal” 310, 1085-1086.

EBM Working Group (1992), Evidence-Based Medicine. A New Approach to Teaching the Practice of Medicine, „Journal of the American Medical Association” 269(17), 2420-2425.

Elstein A. (1999), Heuristics and Biases. Selected Errors in Clinical Reasoning, „Academic Medicine" 74(7), 791-794.

Evans T. B. St. J. (2003), In Two Minds. Dual-Process Accounts of Reasoning, „Trends in Cognitive Sciences" 7(10), 454-459.

Gajewski P., Jaeschke R., Brożek J. (red.) (2008), Podstawy EBM, czyli medycyny opartej na danych naukowych dla lekarzy i studentów medycyny, Kraków: Medycyna Praktyczna.

Gawande A. (2012), Potęga checklisty. Jak opanować chaos i zyskać swobodę $w$ działaniu, Kraków: Znak.

Gigerenzer G. (1996), On Narrow Norms and Vague Heuristics. A Reply to Kahneman and Tversky (1996), „Psychological Review” 103(3), 592-596.

Gigerenzer G., Brighton H. (2009), Homo Heuristicus. Why Biased Minds Make Better Inferences, „Topics in Cognitive Science” 1(1), 107-143.

Gigerenzer G., Gaissmaier W. (2011), Heuristic Decision Making, „Annual Review of Psychology" 62, 451-482.

Grossman J., Mackenzie F. (2005), The Randomized Controlled Trial. Gold Standard or Merely a Standard?, „Perspectives in Biology and Medicine” 48(4), 516-534.

Grzybowski A. (2012), Matematyczne modele konfliktu. Wykłady z teorii gier i decyzji, Częstochowa: Wydawnictwo Politechniki Częstochowskiej.

Guyatt G. H. (1991), Evidence-Based Medicine, „ACP Journal Club” 114, A16.

Guyatt G., Haynes R. B., Jaeschke Z. R., Cook D. J., Green L., Naylor C. D., Wilson M. C., Richardson W. S. (2000), User's Guide to the Medical Literature XXV. EvidenceBased Medicine. Principles for Applying the User's Guides to Patient Care, „Journal of American Medical Association” 284(10), 1290-1296.

Kahneman D. (2012), Pułapki myślenia. O myśleniu szybkim i wolnym, tłum. P. Szymczak, Poznań: Media Rodzina.

Kestin I. (2015), Statistics in Medicine, „Anaesthesia and Intensive Care Medicine” 16(4), 200-207.

Kuhn T. (2009), Struktura rewolucji naukowych, tłum. H. Ostromęcka, Warszawa: Fundacja Aletheia.

Kuklin B. (2006), Probability Misestimates in Medical Care, „Arkansas Law Review” 59, 527-554.

Miettinen S. O. (2001), The Modern Scientific Physician. 3. Scientific Diagnosis, „Canadian Medical Association Journal"18(165), 781-782.

Monahan J. (2007), Statistical Literacy. A Prerequisite for Evidence-Based Medicine, „Psychological Science in the Public Interest” 8(2), s. i-ii. 
Redelmeier A. D., Shafir E. (1995), Medical Decision Making in Situations That Offer Multiple Alternatives, „Journal of the American Medical Association”, 273(4), 302-305.

Reszka P. (2017), Mali bogowie, Warszawa: Czerwone i Czarne.

Rosenberg W., Donald A. (1995), Evidence Based Medicine. An Approach to Clinical Problem-Solving, „British Medical Journal” 310(6987), 1122-1126.

Rzepiński T. (2012), Ewidencja empiryczna $w$ procesie podejmowania decyzji klinicznych, „Filozofia Nauki” 20(3) [79], 13-33.

Sackett D., Rosenberg W. (1995), The Need for Evidence Based Medicine, „Journal of the Royal Society of Medicine" 88(1), 620-624.

Sackett D., Rosenberg W., Gray M. A. J., Haynes R. B., Richardson W. S. (1996), Evidence Based Medicine. What It Is and What It Isn't, „British Journal Medicine” 312(7023), 71-72.

Stanovich E. K., Toplak E. M. (2012), Defining Features versus Incidental Correlates of Type 1 and Type 2 Processing, ,Mind \& Society” 11(1), 3-13.

Stanovich E. K., West F. R. (2000), Individual Differences in Reasoning. Implications for the Rationality Debate?, „Behavioral and Brain Sciences” 23(5), 645-726.

Switzer S. S., Horton J. N. (2007), What Your Doctor Should Know about Statistics (but Perhaps Doesn't), „Chance” 20(1), 17-21.

Szumowski W. (2005), Filozofia medycyny, Kęty: Antyk.

Tatoń J., Czech A. (2002), Diagnostyka internistyczna. Podręcznik dla lekarzy i studentów, Warszawa: Wydawnictwo Lekarskie PZWL.

Tversky A., Kahneman D. (1973), Availability. A Heuristic for Judging Frequency and Probability, „Cognitive Psychology” 5(2), 207-232.

Tversky A., Kahneman D. (1974), Judgement under Uncertainty. Heuristics and Biases, „Science” 185(4157), 1154-1131.

Tversky A., Kahneman D. (1981), The Framing Decision and the Psychology of Choice, „Science” 211(4481), 453-458.

Tversky A., Kahneman D. (1986), Rational Choice and the Framing of Decisions, „The Journal of Business" 59(4), S251-S278.

Wegwarth O., Gaissmaier W., Gigerenzer G. (2009), Smart Strategies for Doctors and Doctors-in-Training. Heuristics in Medicine, „Medical Education” 43(8), 721-728.

West F. A., West R. R. (2002), Clinical Decision-Making. Coping with Uncertainty, „Postgraduate Medical Journal" 78(920), 319-321.

Wolf M. F., Gruppen D. L., Billi E. J. (1985), Differential Diagnosis and the Competing Hypotheses Heuristic. A Practical Approach to Judgement under Uncertainty and Bayesian Probability, „Journal of American Medical Association” 253(19), 2858-2862.

Worrall J. (2010), Evidence. Philosophy of Science Meets Medicine, „Journal of Evaluation in Clinical Practice" 16(2), 356-362.

Wulff R. H., Gøetzsche C. P. (2005), Racjonalna diagnoza i leczenie. Wprowadzenie do medycyny wiarygodnej czyli Evidence-Based Medicine, tłum. Z. Szawarski, Łódź: AKTIS. 